\title{
The organizational culture of a Brazilian public hospital
}

\author{
A CULTURA ORGANIZACIONAL DE UM HOSPITAL PÚBLICO BRASILEIRO
}

\author{
LA CULTURA ORGANIZACIONAL DE UN HOSPITAL PÚBLICO BRASILEÑO
}

Fernanda Ludmilla Rossi Rocha ${ }^{1}$, Maria Helena Palucci Marziale ${ }^{2}$, Michele Cristina de
Carvalho $^{3}$, Samira de Fátima Cardeal dd $^{4}$, Monica Chiodi Toscano de Campos

\begin{abstract}
The objective of this research was to analyze the organizational culture of a Brazilian public hospital. It is a descriptive study with quantitative approach of data, developed in a public hospital of São Paulo State, Brazil. The sample was composed by 52 nurses and 146 nursing technicians and auxiliaries. Data were collected from January to June 2011 using the Brazilian Instrument for Assessing Organizational Culture - IBACO. The analysis of the organizational values showed the existence of hierarchical rigidity and centralization of power within the institution, as well as individualism and competition, which hinders teamwork. The values concerning workers' well-being, satisfaction and motivation were not highly valued. In regard to organizational practices, the promotion of interpersonal relationship, continuous education, and rewarding practices were not valued either. It becomes apparent that traditional models of work organization support work practices and determine the organizational culture of the hospital.
\end{abstract}

\section{DESCRIPTORS}

Nursing

Organizational culture

Health administration

Health Services

\section{RESUMO}

O objetivo deste estudo foi analisar a cultura organizacional de um hospital público brasileiro. Trata-se de pesquisa descritiva, com abordagem quantitativa dos dados, desenvolvida em um hospital público do Estado de São Paulo. A amostra foi composta por 52 enfermeiros e 146 técnicos e auxiliares de enfermagem. Os dados foram coletados entre janeiro e junho de 2011, sendo utilizado o Instrumento Brasileiro para Avaliação da Cultura Organizacional - IBACO. A análise dos valores organizacionais demonstrou existência de rigidez hierárquica, centralização de poder, individualismo e competição no trabalho, dificultando o desenvolvimento do trabalho em equipe. Valores de bem-estar, satisfação e motivação dos trabalhadores foram pouco considerados. Em relação às práticas organizacionais, a promoção de relações interpessoais, as práticas de educação permanente e a recompensa dos trabalhadores também foram pouco valorizadas. Fica evidenciado que modelos tradicionais de organização do trabalho sustentam as práticas de trabalho do hospital e determinam a cultura organizacional.

\section{DESCRITORES \\ Enfermagem \\ Cultura organizacional \\ Administração em saúde \\ Serviços de Saúde}

\section{RESUMEN}

El objetivo de este estudio fue analizar la cultura organizacional de un hospital público brasileño. Corresponde a una investigación descriptiva con enfoque cuantitativo de los datos, desarrollada en un hospital público en el estado de São Paulo. La muestra estuvo conformada por 52 enfermeras y 146 técnicos y auxiliares de enfermería. Los datos fueron recogidos entre enero y junio de 2011, y se utilizó el Instrumento Brasileño para la Evaluación de la Cultura Organizacional - IBACO. El análisis de los valores de la organización demostró la existencia de una jerarquía rígida, la centralización del poder, el individualismo y la competencia en el trabajo, dificultando el desarrollo del trabajo en equipo. Los valores de bienestar, satisfacción y motivación de los trabajadores fueron poco considerados. En relación a las prácticas de la organización, la promoción de las relaciones interpersonales, las prácticas de educación continua y las prácticas de recompensa de los trabajadores también fueron infravaloradas. Se evidencia que los modelos tradicionales de organización del trabajo soportan las prácticas de trabajo del hospital y determinan la cultura organizacional.

\section{DESCRIPTORES \\ Enfermería \\ Cultura organizacional \\ Administración en salud \\ Servicios de Salud}

${ }^{1}$ RN, PhD. Professor of General and Specialized Nursing Department, School of Nursing of Ribeirão Preto, University of São Paulo, Ribeirão Preto, São Paulo, Brazil. ferocha@eerp.usp.br ${ }^{2}$ RN, Full Professor of General and Specialized Nursing Department, School of Nursing of Ribeirão Preto, University of São Paulo, Ribeirão Preto, São Paulo, Brazil. marziale@eerp.usp.br ${ }^{3}$ Undergraduate student, School of Nursing of Ribeirão Preto, University of São Paulo, Ribeirão Preto, São Paulo, Brazil. michele.carvalho@usp.br ${ }^{4}$ RN. School of Nursing of Ribeirão Preto, University of São Paulo, Ribeirão Preto, São Paulo, Brazil. samiracardeal@hotmail.com 5 Professor of University of Brasilia, Brasília, DF, Brazil. monica.chiodi@uol.com.br 


\section{INTRODUCTION}

Culture is a historical and social construction that comprises knowledge, morality and standards that guide the behavior of a group; it is characterized by individuals' experiences, beliefs and values, which can be learned and shared and transmitted from generation to generation ${ }^{(1)}$.

Culture can represent more than a set of rules, habits and artifacts. It also means an organism full of meanings where individuals from the same group share them, functioning as a collective pattern of identification of different groups with their specific ways of thinking, feeling and acting(2).

Organizations are seen as micro societies included in a social context with which they interact, influencing it and being influenced by it. They represent cultural, symbolic and imaginary systems, composed of a structure of values and standards that condition the behavior of its members and guide their practices ${ }^{(3)}$.

Organizations are composed of people who constantly interact with each other, and are thereby considered to be dynamic processes in which the cultural formation of individuals and specific groups take place on a continuous basis ${ }^{(4)}$. Therefore, workers are agents in organizations and their personal values become elements of the organizations' culture ${ }^{(2)}$.

An organizational culture can be seen as a process of construction and sharing of the reality of an institution. It plays an essential role in the lives of organizations and can be seen as a set of meanings shared by their members, which configures a collective identity ${ }^{(5)}$.

In this context, the perceptions of the members of an organization express shared beliefs and represent organizational values, forming the core of organizational culture. Organizational values can be considered formative aspects of the organization's basis, constituting the diverse dimensions of the institution and have the function of guiding life in a company and the daily behavior of workers. Organizational values can therefore influence the workplace and the functioning of organizations, determining common directions for workers ${ }^{(6-7)}$. Moreover, organizational values have also been shown to impact quality of care and safety culture in different health services worldwide ${ }^{(8-11)}$.

Given our understanding concerning the inter-relationships among individuals, organizational culture and health organizations, we became motivated to conduct this study whose objective was to analyze the organizational culture of a public hospital from the perspective of nursing workers.

\section{METHOD}

This descriptive study with quantitative approach was based on the framework of Hofstede ${ }^{(12)}$. It was developed in a public hospital in the interior of São Paulo State, Brazil, classified as a high-complexity hospital, linked to the Unified Health System (SUS).

The study's population was represented by 213 nurses and 923 nursing technicians and auxiliaries working in different sectors in the institution: hospitalization units in the Surgical Ward, Intensive Therapy units, and Ambulatory units of Medical Specialties.

Stratified random sampling was used to define the sample size. Using a precision level of $5 \%, N_{1}=213$, $\mathrm{N}_{2}=923$ and maximizing equal proportions of workers who have a negative view of the organizational culture, that is, $p_{1}=p_{2}=0.50$, we have the total sample sizes for the two categories, totaling a proportion of $10 \%$, were given by: $n_{1}=62$ (number of nurses) and $n_{2}=265$ (number of nursing technicians and auxiliaries).

Inclusion criteria: nursing workers who were not on leave during the data collection period and answered at least $50 \%$ of the questions of the forms used to collect data.

The data collection instrument was composed of two parts. The first part addressed the categorization of workers (age, gender, marital status, education, workplace) and the second part comprised the Brazilian Instrument for Assessing Organizational Culture-IBACO ${ }^{(13)}$.

IBACO was developed by Brazilian researchers based on the Hofstede's Theory ${ }^{(12)}$. It objective is to assess values and practices that shape the culture of an organization from the perspective of workers. This instrument presents 55 items distributed into four factors related to organizational values: values concerning cooperative professionalism, rigidity in the hierarchical structure of power, competitive and individualist professionalism, and wellbeing and satisfaction. IBACO also presents 39 items distributed into three factors related to organizational practices: external integration practices, rewarding and training practices, and practices concerning the promotion of interpersonal relationships.

Data were collected from January to June 2011 through the application of the instrument in workplaces during the work shifts of the study's participants, who signed a consent form.

The study's project was submitted to and approved by the institution's Ethics Research Committee (protocol $3117 / 2010$ ). The study complied with guidelines provided by Resolution 466/2012 concerned ethical standards for research involving human subjects ${ }^{(14)}$.

\section{RESULTS}

A total of 52 out of the 62 selected nurses agreed to participate in the study and returned the completed instruments. Two nurses refused to participate in the study; three were no longer working in the facility; one was on health leave, and four nurses had been transferred to other units and were therefore excluded from the sample. 
We verified that 16 out of the 52 participants were coordinators (30.77\%); women (96.15\%), and workers aged from 31 and 50 years old (71.16\%); married individuals (59.62\%) predominated; ten nurses $(19.23 \%)$ had master's degrees and only seven nurses (13.46\%) reported another job.

Of the total of 265 nursing auxiliaries and technicians selected, 146 participated in the study. Of the 119 participants who did not participate in the study, 42 refused to participate, 28 did not return the questionnaire, 23 were on sick leave, 20 were on vacation, and six no longer worked in the facility.

We verified that $78.1 \%$ of these workers were women; $64.5 \%$ were 31 to 50 years old; $54.1 \%$ were married; $71.3 \%$ had completed secondary school; $85.6 \%$ were nursing auxiliaries and $82.2 \%$ did not report another job.

\section{Values and practices that characterize the organizational culture}

IBACO ${ }^{(13)}$ presents 94 statements, 55 of which are related to four types of organizational values: Cooperative Professionalism (CP), Rigidity in the Hierarchical Structure (RH), Competitive and Individualistic Professionalism (CIP), and values associated with the workers' Satisfaction and Well Being (SW). The remaining 39 statements are related to three categories of organizational practices: External Integration (EI) practices, Rewarding and Training (RT) practices, and Interpersonal Relationship Promotion (IRP) practices.

$\mathrm{CP}$ concerns values concerning the valorization of workers who perform tasks efficiently and competently, showing a spirit of collaboration, dedication, professionalism, and initiative, therefore, contributing to the achievement of the organization's goals. $\mathrm{RH}$ refers to values that define the organization as a system of centralized authority, not acknowledging the human element and hindering professional growth. CIP refers to the acknowledgment of individual competence and performance in result-driven tasks, not acknowledging collective work. SW, in turn, refers to the acknowledgement of workers' wellbeing, satisfaction and motivation.

El refers to practices related to strategic planning actions, decision-making and serving the organization's external client. RT refers to practices linked to rewarding and training systems for workers and also to meeting the needs of internal clients. IRP refers to practices concerning the promotion of interpersonal relationships and worker satisfaction, favoring internal cohesion.

In order to answer the questionnaire, the participant checks, based on his/her perception, the statement that somewhat (one point), little (2 points), reasonably (3 points), very much (4 points) or totally (5 points) applies to the organization. The average of scores assigned by the respondents to each factor is computed for data analysis. Scores range from 1 to 5 , while the higher the result, the higher the degree to which the organization's value or practice, measured by that specific factor, is present in the organization.

The answers provided by the nurses resulted in an average score of 3.06 for the values concerning cooperative professionalism; 3.22 for values related to hierarchical rigidity and the centralization of power; 2.27 for individualistic professionalism and competition at work; 2.32 for values related to wellbeing and the motivation of workers. In relation to organizational practices, we verified an average of 3.51 for external integration; 2.20 for rewarding and training practices, and 2.94 for practices related to the promotion of interpersonal relationships at the hospital.

The answers provided by the nursing auxiliaries and technicians obtained an average score of 2.64 for cooperative professionalism; 2.81 for hierarchical rigidity and the centralization of power; 2.19 for individualistic professionalism and competition at work; 2.13 for worker well-being and motivation. In relation to organizational practices, we verified an average of 3.44 for external integration practices, 1.87 for rewarding and training practices, and 2.57 for practices related to the promotion of interpersonal relationship within the organization. Data are presented in Table 1.

No discrepancies were found between the answers of the two groups, despite the higher average scores obtained by the answers provided by nurses compared to those provided by nursing auxiliaries and technicians.

Table 1 - Average scores of organizational values and practices from the perspective of nursing workers in a public hospital in the interior of the state of São Paulo, Brazil 2011

\begin{tabular}{|c|c|c|c|c|c|c|c|c|}
\hline \multirow{2}{*}{$\begin{array}{l}\text { Values/ } \\
\text { Practices }\end{array}$} & \multicolumn{4}{|c|}{ Nurses $(n=52)$} & \multicolumn{4}{|c|}{ Nursing technicians and auxiliaries $(n=146)$} \\
\hline & Average & Median & $\begin{array}{l}\text { Standard } \\
\text { deviation }\end{array}$ & $\begin{array}{l}\text { Minimum- } \\
\text { Maximum }\end{array}$ & Average & Median & $\begin{array}{l}\text { Standard } \\
\text { deviation }\end{array}$ & $\begin{array}{l}\text { Minimum - } \\
\text { maximum }\end{array}$ \\
\hline $\mathrm{CP}$ & 3.06 & 3.20 & 0.48 & $1.9-4.4$ & 2.64 & 2.60 & 0.72 & $1.1-4.3$ \\
\hline $\mathrm{RH}$ & 3.22 & 3.20 & 0.39 & $2.4-4.4$ & 2.81 & 2.80 & 0.58 & $1.2-4.5$ \\
\hline CIP & 2.27 & 2.30 & 0.40 & $1.5-3.0$ & 2.19 & 2.05 & 0.67 & $1.0-5.0$ \\
\hline SW & 2.32 & 2.40 & 0.51 & $1.2-3.5$ & 2.13 & 2.10 & 0.69 & $1.0-4.0$ \\
\hline EI & 3.51 & 3.50 & 0.41 & $2.6-4.4$ & 3.44 & 3.50 & 0.59 & $1.8-4.7$ \\
\hline RT & 2.20 & 2.30 & 0.40 & $1.2-3.0$ & 1.87 & 1.85 & 0.45 & $1.0-3.2$ \\
\hline IRP & 2.94 & 2.90 & 0.50 & $1.8-4.0$ & 2.57 & 2.50 & 0.64 & $1.1-4.4$ \\
\hline
\end{tabular}

Note: $(\mathrm{n}=198)$ 


\section{DISCUSSION}

Based on the study of the psychodynamics of health work, we assert that the organizational structure and management model adopted by an organization determine the work processes and behaviors of workers. Additionally, we understand that there are values, beliefs, habits and practices implicit in work places that are shared among the members of an organization, defining behavioral standards and ways of organizing work.

This set of values and practices, expressed through rituals, myths, habits and beliefs common to workers, represents the organizational culture, which defines the characteristics of each institution and is considered to be the foundation of an organization ${ }^{(4)}$.

The analysis of organizational values of the studied hospital shows that nurses find the existence of hierarchical rigidity and the centralization of power in the institution (average $\mathrm{RH}=3.22$ ); believed there was cooperation among workers (average $\mathrm{CP}=3.06$ ), though they perceived individualism and competition (average $\mathrm{CIP}=2.27)$, each of which hinders the development of teamwork-based practices. They also believed that values associated with the workers' well-being, satisfaction and motivation were seldom acknowledged by the hospital (average $S W=2.32$ ). In relation to organizational practices, the nurses believed in the adoption of strategic planning actions within the institution (average $\mathrm{El}=3.51$ ), but considered interpersonal relationship promotion (average IRP=2.94), continuous education and the rewarding of workers (average $\mathrm{RT}=2.20$ ) to be little valued by the institution.

The answers of nursing technicians and auxiliaries also showed they believed there was cooperation and collaboration (average $\mathrm{CP}=2.64$ ), despite the existence of competition among workers; there was hierarchical rigidity and the centralization of power in the institution (average $\mathrm{RH}=2.81$ ), while workers' well-being and motivation were seldom acknowledged by the institution (average $\mathrm{SW}=2.13$ ). In relation to organizational practices, the promotion of interpersonal relationships (average $I R P=2.57$ ) and training interventions and worker rewards (average RT=1.87) were under-valued within the hospital.

Therefore, this study's results reveal that the values and practices that define the culture of the studied hospital are closely related to the organization and management model adopted by the facility. Hence, the institution's culture presents elements related to rigid organizational structure and the centralization of power; existence of competition among workers, individualism and difficulty developing teamwork; lack of interest on the part of the hospital in the workers' well-being and the promotion of interpersonal relationships, disregarding the needs of workers.
Organizational culture is a result of a society's cultural dynamics, in which organizations are included ${ }^{(12)}$. Seeking to confirm this assumption, the researchers performed a study in 76 countries, including Brazil, initially identifying the cultural elements present in all the nations. After identifying the countries' cultural characteristics, they performed a study of different organizations within these countries and verified that organizational culture is directly influenced by national culture.

These studies enabled the development of theoretical assumptions related to different dimensions of the organizational culture. The dimensions are dynamic and interdependent and represent the practices and values that characterize the culture of organizations. Among these dimensions, we highlight: process-oriented versus result-oriented cultures; work-oriented versus worker-oriented; weak control over work versus strong control over work in organizations ${ }^{(12)}$.

According to these authors, process-oriented and work-oriented organizations present rigid structures, the centralization of power, strong work specialization, formal relationships and difficult communication. Processes are highly controlled, as are workers, who suffer pressure from managers while performing their tasks, are not allowed to participate in decision-making and feel their personal problems do not matter to the organization.

On the contrary, result- and worker-oriented organizational cultures present less hierarchical levels and participatory decision-making, concerning for workers' needs, which is expressed through valuing their well-being and satisfaction.

Brazilian public health services are examples of processand work-oriented organizations. Their hierarchical structure is predominantly authoritarian with centralized decisionmaking, excessive control of procedures, rigid administration not focused on local needs, and a context in which change is difficult due to a lack of entrepreneurial behavior ${ }^{(2,15)}$.

These findings corroborate other national studies addressing the influence of the Brazilian culture on organizations, showing that Brazilian history reflects on the history of the Brazilian administration and consequently on the culture of public organizations.

Similarly to the Brazilian cultural history, the history of Brazilian administration is marked by a constant struggle between a formal, centralizing and ritualistic bureaucracy that is averse to change, which is linked to conservative economic interests, and a modernizing tendency that seeks news management models that move toward globalization and neoliberalism ${ }^{(16)}$.

For this reason, Brazilian public organizations present authoritative organizational structures with excessive centralization of decision power and excessive control of procedures, which leads to rigid administration styles and paternalism ${ }^{(15)}$. There is an attachment to rules, routines and to power and the overvaluation of hierarchy, 
characteristics that hinder changing processes and that define organizational values and beliefs, as well as the human resources policy adopted by the company ${ }^{(2)}$.

Additionally, these elements are related to traditional management models and work organization, present from the time productive structuring of health services and nursing in Brazil. The traditional models are based on the logic of legal authority inherited from the classical conception of administration and characterized by hierarchical and authoritative structures, in which communication and interpersonal relationships are formalized, tasks are fragmented, with an emphasis on organization and work processes with devaluation of individuals ${ }^{(17)}$.

Authority and the social division of nursing work, often embedded in rigid hierarchies, lead to estrangement and conflicts among workers ${ }^{(18)}$, which may explain a lack of cooperation among workers and the difficulty that exists in developing interdisciplinary work and teamwork in institutions.

Conflictive relationships in the health work result from its complexity, since the health field involves different professions, each with its own specificity and historically constructed culture. In this context, nurses' work is based on the profession's historical and cultural context. Nurses play both managerial and care roles and are the element responsible for the composition of service, interpersonal relationships and the coordination of work. Moreover, the management role of nurses is marked by control mechanisms and power related to military and religious influences inherent to the profession's history ${ }^{(19)}$.

In addition to these characteristics, healthcare delivery follows the principles of the biomedical model, which values medical knowledge, specialization of actions, submission of other professions to physicians, and a fragmented view of the human being, which in turn leads to fragmented care, the lack of humanization and integrality in care, and a lack of teamwork and interdisciplinary work. The main consequence of this process is low quality care delivered to patients.

This work context in the heath field can lead to a lack of motivation and professional dissatisfaction, hindering workers from developing their full potential and skills and, consequently, harming their professional growth, potentially even leading to occupational diseases.

Unfavorable conditions impeding workers from having freedom and control over their work may generate fear, insecurity, despair and psychological suffering, which in turn can trigger anxiety, depression, personality disorders and burnout syndrome. Occupational mental disorders result from the sum of difficulties faced daily in the work context and the interaction of these factors with the workers' individual characteristics ${ }^{(20)}$.

Burnout represents a process that develops in the interaction of workplace characteristics and the workers' personal characteristics, manifesting itself as burnout or emotional exhaustion, reduced personal accomplishment and depersonalization ${ }^{(20)}$. A study performed with health workers indicates that there is an association between organizational values and the occurrence of burnout syndrome. The results enabled the authors to understand this syndrome as a process with multiple determinants, in which organizational values are important elements. The promotion of human values would represent a strategy to prevent this syndrome ${ }^{(21)}$.

It's been observed, however, a productive and organizational restructuring process in the health work context, as the taylorist-fordist model has been depleted and new productive scenarios emerge due to the need to revise work organization and management. In the nursing field, integral care practices with an interdisciplinary focus stand out, as do those related to the humanization of the workplace, to the participatory management of services, continuous education, as a way to ensure the continuous development of workers, and practices related to motivational actions ${ }^{(22)}$.

Additionally, contemporary health practices have become the focus of attention due to new conceptions of the human being, currently seen as a social being and agent of care ${ }^{(23)}$. The valorization of the human dimension and feelings present in work relations are highlighted in a process in which interdisciplinary teams are implemented with greater integration and cooperation among the different professionals ${ }^{(24)}$. Moreover, organizational values related to the valorization of the human dimension have been considered essential to enhance the quality of care in health services worldwide ${ }^{(8-11)}$.

The demands for nursing that emerge have shown that the health work should not be fragmented, impersonal or devoid of affection. On the contrary, the establishment of bonds among the different social actors is needed in order to welcome and empower people, which requires one to understand health as a right, including the health of workers. The routine, mechanical work that is, devoid of pleasure, creativity and subjectivity, should be replaced by pleasant, bold, and creative practices, moving toward the reconstruction of a new way of providing care, based on the satisfaction of individual needs in the workplace, whose solutions are not found in any manual of rules and routines ${ }^{(25)}$.

Similarly, challenges resulting from the implementation of the principles of universality, equity, and integrality in the SUS require a review of the role of each institution in its relationship with users, being essential to decentralizing power and leveling relationships, developing more autonomy and new professional competencies.

\section{CONCLUSION}

This study's results provide evidences of the relationship between the organizational culture and the 
management model and work organization adopted by the health institution. Traditional administration models and principles of scientific organization of work, historically incorporated by managers and workers in the institution, together support work practices and determine organizational values and practices.

Hence, based on the perception of workers, organizational values and practices permeate hierarchy, assert control over work and rigidity, individualism, and competition among individuals and the devaluation of workers. This conception of work leads to a fragmentation of care delivered to patients, and also hinders teamwork, the development of interdisciplinary health care actions and the achievement of quality care delivery.

Moreover, these characteristics of work within the facility lead to dissatisfaction and lack of motivation as the workers' needs and competencies are not taken

\section{REFERENCES}

1. Helman CG. Cultura, saúde e doença. 5ạ ed. Porto Alegre: Artes Médicas; 2009.

2. Pires JCS, Macedo KB. Cultura organizacional em organizações públicas no Brasil. Rev Adm Pública. 2006;40(1):81-105.

3. Schein EH. Organizational culture and leadership. 4th ed. San Francisco: Jossey-Bass; 2010.

4. Santos SR. Cultura nas instituições de saúde e suas relações com a identidade individual. Cogitare Enferm. 2007;12(2):229-35.

5. Vaitsman J. Cultura de organizações públicas de saúde - notas sobre a construção de um objeto. Cad Saúde Publica. 2000;16(3):847-50.

6. Tamayo A, organizador. Cultura e saúde nas organizações. Porto Alegre: Artmed; 2004.

7. Azevedo CS, Braga Neto FC, SÁ MC. Indivíduo e a mudança nas organizações de saúde: contribuições da psicossociologia. Cad Saúde Pública 2002;18(1):235-47.

8. Tyagi RK, Cook L, Olson J, Belohlav J. Healthcare technologies, quality improvement programs and hospital organizational culture in Canadian hospitals. BMC Health Serv Res. 2013;13:413.

9. Belohlav JA, Cook LS, Olson JR, Drehmer DE. Core values in hospitals: a comparative study. Qual Manage J. 2010;7(4):36-50.

10. Khatri N, Halbesleben JRB, Petroski GF, Meyer W. Relationship between management philosophy and clinical outcomes. Health Care Manage Rev. 2007; 32(2):128-39. into account, hindering professional growth and compromising the quality of care even further.

Hence, we deem it necessary to transform heath care practices through the adoption of new forms of management and work organization, which have been studied and implemented in diverse institutions in the attempt to replace traditional models, advocating participatory management, teamwork, acknowledgement of individuals' needs (of both patients and workers), integrality of care, the humanization of interpersonal relationships, and comprehending the human being as agent of health actions.

We believe, however, that this change will be effective only when values shared among individuals, and which form the culture of organizations, also change. Such a process can contribute to the improvement of the quality of health care and should be initiated by managers and work coordinators.

11. Stock GN, McFadden KL, Gowen CR III. Organizational culture, critical success factors, and the reduction of hospital errors. Int J Prod Econ. 2007;106(2):368-92.

12. Hofstede G, Hofstede GJ, Minkov M. Cultures and organizations: software of the mind. Intercultural cooperation and its importance for survival. 3rd ed. New York: McGraw Hill; 2010.

13. Ferreira MC, Assmar EML. Cultura organizacional. In: Siqueira MMM, organizador. Medidas do comportamento organizacional: ferramentas de diagnóstico e de gestão. Porto Alegre: Artmed; 2008. p.125-38.

14. Conselho Nacional de Saúde. Resolução n. 466, de 12 de dezembro de 2012. Dispõe sobre as diretrizes e normas regulamentadoras de pesquisas envolvendo seres humanos [Internet]. Brasília; 2012 [citado 2013 set. 17]. Disponível em: http://conselho.saude.gov.br/resolucoes/2012/Reso466.pdf

15. Carbone PP. Cultura organizacional no setor público brasileiro: desenvolvendo uma metodologia de gerenciamento da cultura. Rev Adm Pública. 2000;34(2):133-44.

16. Castor BVJ, José HAA. Reforma e contra-reforma: a perversa dinâmica da administração pública brasileira. Rev Adm Pública. 1999;32(6):97-111.

17. Matos E, Pires D. Teorias administrativas e organização do trabalho: de Taylor aos dias atuais, influências no setor saúde e na enfermagem. Texto Contexto Enferm. 2006;15(3):508-14.

18. Vaghetti HH, Padilha MICS, Lunardi Filho WD, Lunardi VL, Costa CFS. Significados das hierarquias no trabalho em hospitais públicos brasileiros a partir de estudos empíricos. Acta Paul Enferm. 2011;24(1):87-93. 
19. Prochnow AG, Leite JL, Erdmann AL, Trevizan MA. O conflito como realidade e desafio cultural no exercício da gerência do enfermeiro. Rev Esc Enferm USP 2007;41(4):542-50.

20. Brasil. Ministério da Saúde; Organização Pan-Americana da Saúde. Doenças relacionadas ao trabalho: manual de procedimentos para os serviços de saúde. Brasília; 2001.

21. Borges LO, Lima MAS, Vilela EC, Morais SSG. A síndrome de Burnout e os valores organizacionais: um estudo comparativo em hospitais universitários. Psicol Reflex Crít. 2002;15(1):189-200.

22. Abrahão JI, Pinho DLM. As transformações do trabalho e desafios teórico-metodológicos da ergonomia. Estudos Psicol (Natal). 2002;7(n.esp):45-52.
23. Erdmann AL, Andrade SR, Mello ALSF, Meirelles BHS. Gestão das práticas de saúde na perspectiva do cuidado complexo. Texto Contexto Enfem. 2006;15(3):483-91.

24. Kurcgant $P$, Massarollo MCKB. Cultura e poder nas organizações de saúde. In: Kurcgant P, coordenadora. Gerenciamento em enfermagem. 2aed. São Paulo: Guanabara Koogan; 2010. p. 23-33.

25. Rossi FR, Silva MAD. Fundamentos para processos gerenciais na prática do cuidado. Rev Esc Enferm USP. 2005;39(4):460-8. 